\title{
Landslide susceptibility mapping by combining the three methods Fuzzy Logic, Frequency Ratio and Analytical Hierarchy Process in Dozain basin
}

\author{
Esmaeil Tazik $^{\text {a. }}$, Zahra Jahantab ${ }^{\text {b }}$, Mohsen Bakhtiari ${ }^{\text {a }}$, Abdolali Rezaei ${ }^{\text {a* }}$, Seyed Kazem Alavipanah ${ }^{\text {a }}$ \\ ${ }^{a}$ Dept. of RS\&GIS, Faculty of Geography, University of Tehran, Iran \\ ${ }^{\mathrm{b}}$ Dept. of RS\&GIS, Faculty of Environment, Islamic Azad University, Iran - Rezai.al.65@gmail.com
}

KEY WORDS: Landside susceptibility, Fuzzy Analytical Hierarchy Process, frequency ratio

\begin{abstract}
:
Landslides are among the most important natural hazards that lead to modification of the environment. Therefore, studying of this phenomenon is so important in many areas. Because of the climate conditions, geologic, and geomorphologic characteristics of the region, the purpose of this study was landslide hazard assessment using Fuzzy Logic, frequency ratio and Analytical Hierarchy Process method in Dozein basin, Iran. At first, landslides occurred in Dozein basin were identified using aerial photos and field studies. The influenced landslide parameters that were used in this study including slope, aspect, elevation, lithology, precipitation, land cover, distance from fault, distance from road and distance from river were obtained from different sources and maps. Using these factors and the identified landslide, the fuzzy membership values were calculated by frequency ratio. Then to account for the importance of each of the factors in the landslide susceptibility, weights of each factor were determined based on questionnaire and AHP method. Finally, fuzzy map of each factor was multiplied to its weight that obtained using AHP method. At the end, for computing prediction accuracy, the produced map was verified by comparing to existing landslide locations. These results indicate that the combining the three methods Fuzzy Logic, Frequency Ratio and Analytical Hierarchy Process method are relatively good estimators of landslide susceptibility in the study area. According to landslide susceptibility map about $51 \%$ of the occurred landslide fall into the high and very high susceptibility zones of the landslide susceptibility map, but approximately $26 \%$ of them indeed located in the low and very low susceptibility zones.
\end{abstract}

\section{INTRODUCTION}

Global climate change and the increasing human population over the past few decades have deeply affected the geoenvironment [Wang et al, 2013]. Landslide is a major cause of substantial damages that lead to property and loss of life in many countries across the world every year. It is a major geohazard and can be triggered by earthquakes, volcanic eruptions, flood, or indeed by man-made activities. Landslide susceptibility is defined as the proneness of the terrain to produce slope failures, and it is usually expressed in a cartographic way. A landslide susceptibility map depicts areas likely have landslides in the future by correlating some of the principal factors that contribute to landslides with the past distribution of slope failures [Brabb et al., 1984]. Up to now, several algorithms and models have been proposed for generating the Landslide Susceptibility that mainly include Analytical Hierarchy Process ( AHP) [khazeri et al., 2010],logistic regression[Carrara et al.,1983],fuzzy-logic[Gee et al., 1991],artificial neural network analysis[Canani et al ,2008] modeling approaches[Perriello Zampelli et al ,2012] , Fuzzy Analytical Hierarchy Process (FAHP) [Shadman Roodposhti et al., 2010], Geographically weighted principal component analysis [Faraji Sabokbar et al., 2014] etc, that most of which are related to the weight of landslide factors. Above studies demonstrate that many techniques have been used for landslide susceptibility mapping and have achieved excellent results. Therefore, FAHP, as a common and important technique, for landslide susceptibility mapping, was used to create a landslide susceptibility mapping for Dozein basin, Iran. The main difference between present study and the approaches described before is that we combined three model AHP, Fuzzy logic and frequency ratio to calculate landslide susceptibility hazard in Dozein basin. Therefore, it is predicted to have better results rather than past studies.

\section{Materials and Methods}

\subsection{Study area}

The study area is located east of Golestan province in north Iran, It covers an area of about 5041 ha between longitudes $55^{\circ} 32^{\prime} \mathrm{E}$ and $55^{\circ} 38^{\prime} \mathrm{E}$, and latitudes $37^{\circ} 3 \mathrm{~N}$ and $37^{\circ} 09^{\prime} \mathrm{N}$. In this area several landslides have occurred in the past and now (Fig. 2). The altitude varies from 500 to $2420 \mathrm{~m}$, and it decreases from the northwest to the southeast. Mean annual precipitation and temperature within the study area is $881 \mathrm{~mm}, 17 \mathrm{C}^{\circ}$, respectively. Location map of the study area is shown in Fig 1.

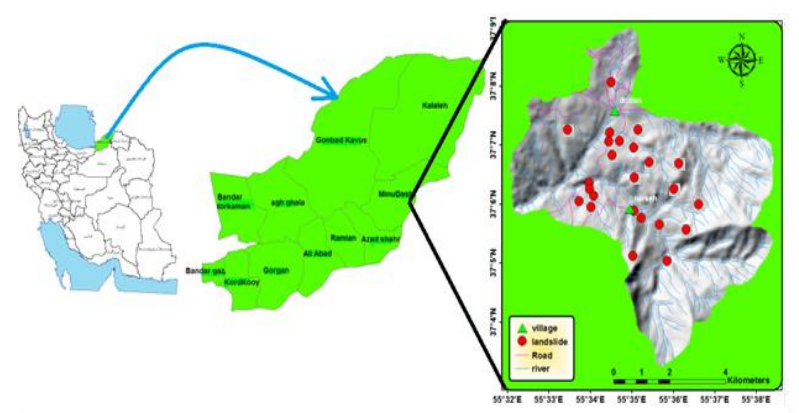

Figure 1. Location map of the study area 


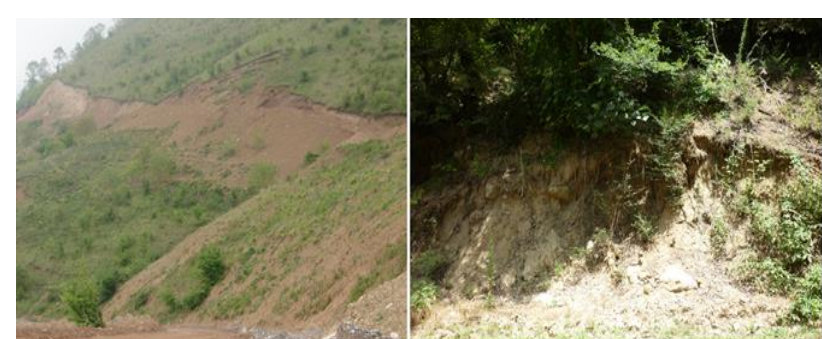

Figure 2. Photos of Landslide in Study area

\subsection{Factors}

At the beginning, in the present study, through field work and review of previous works, the nine factors includig aspect, slope, elevation, land use, lithology, distance from fault, distance from road, distance from river and precipitation were recognized as primary effective factors on landslide occurrence.

\section{Aspect}

Despite the fact that some authors (Greenbaum et al., 1995) mentioned that aspect has no significant influence on land sliding, several researchers have reported a relationship between slope orientation and landslide occurrence (DeGraff et al., 1980, Marston et al. 1998). Aspect-related parameters such as exposure to sunlight, drying winds, rainfall (wetness or degree of saturation) and discontinuities may control the occurrence of landslides .In this study slope aspect is divided every $45^{\circ}$. Thus there are 8 intervals

\section{Slope}

Slope is one of the major factors in landslide susceptibility map because slope have direct effect on landslide process, therefore it is frequently used in landslide susceptibility map [Ayalew et al., 2005, Jordan et al, 2000]

\section{Elevation}

Some researchers use elevation as a controlling parameter for landslides [Creighton et al, 2006]. But some researchers have found that landslide activity, within a specific basin, occurs at certain elevations [Hatamifar et al., 2012], but the relationship between landslide activity and elevation is still unclear, hence it requires further studies. However, in most regions of the Northern Hemisphere, relations between elevation and the rainfall is directly but in some area such as the southern slopes of the Alborz Mountains this relation is inversly, on the other hand elevation have a direct relation with temperature of air, so that by changing these two parameters (rainfall and temperature), amount of storage water, vegetation and evapotranspiration ,etc. Is change that these parameters have negative or positive affect on landslide In this study elevation is divided for every $500 \mathrm{~m}$; thus there are 4 categories

\section{Land cover}

Landslides are natural occurring phenomena and will occur whether people are there or not. However, human practice may accelerate the occurrence or play a significant role in the occurrence of landslides [Cheng et al, 2007]. Land cover is mainly dominated by various types of woods, rangeland, grassland residential area and cultivated land [Dai et al, 2001].

\section{Lithology}

It has been widely recognized that lithology greatly influences the occurrence of landslides, because lithological and structural variations often lead to a difference in the strength and permeability of rocks and soils [Champati ray et al ,2007]. Lithology is one of the main factors for landslide susceptibility zonation [Kayastha et al ,2013].

\section{Distance from faults}

Faults are the structural features, which describe a zone of weakness with relative movement, along which landslide susceptibility is higher [Pourghasemi et al ,2009]. It has generally been observed that the probability of landslide occurrence increases as the mentioned distance decreases, which not only affect the surface material structures but also make contribution to terrain permeability causing slope instability [Iovine et al, 2008]

\section{Distance from road}

The distance to road parameter reflects human activities [Pourghasemi et al., 2009]. In other words, landslides may occur on the slopes intersected by roads [Nielsen et al, 1979]. According to recent studies, cutting slopes for highway construction and frequency vibrations caused by cars would induce landslides (Mittal et al., 2008).Distance from river

Generally, potential of landslides increases by decrease in distance to rivers, because streams may adversely affect stability by eroding the slopes or by saturating the lower part of material, resulting in water level increases [Ercanoglu et al., 2004].

\section{Precipitation}

Most of the landslides occur after heavy rainfall; so that water infiltrates rapidly upon heavy rainfall and increases the degree of saturation and potential of landslide occurrence [Pourghasemi et al., 2009]. Annual total rainfall in this basin is $881 \mathrm{~mm}$ thus precipitation is one of major parameters in the area study.

\subsection{Data}

In this study, a spatial database considering landslide-related factors(Fig.3) based on extensive field work and previous inventory maps, such as topography, geology, and land cover, was used. Land cover was detected from satellite images such as TM images. The landslide map is in the form of point coverage, the topographic map in the form of line and point coverage at a scale of 1:50,000, the geological map in the form of polygon coverage at a scale of 1:50,000. Nine factors, extracted from the constructed spatial database, were considered when calculating the probability.

Contour and survey base points that have an elevation value were extracted from the topographic map was made using the elevation value. The slope, aspect, and elevation were obtained from the Digital Elevation Model (DEM) using IDW model. The distance from river and road was calculated using the topographic map. A lithology and fault map of the study area is digitized from the existing geology map at the scale of $1: 100,000$ from the geological survey of Iran (GSI). Finally, land cover data was classified from a LANDSAT TM image using the supervised (maximum likelihood) classification method. Overall, the Dozein basin data set comprised of 283 rows by 251 columns, with a total cell number of 71033

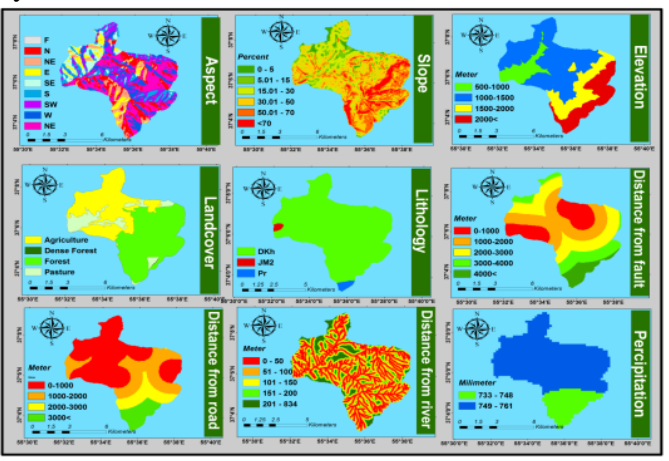

Figure 3. Input data layers 


\subsection{Analysis}

The analytic hierarchy process (AHP) is one of the most commonly used methods of assessment which works base on a premise that decision making of complex problems can be handled by structuring the complex problem into a simple and comprehensible hierarchical structure. Despite of its wide range of applications, the conventional AHP approach may not fully reflect a style of human thinking, in which human's judgments are represented as exact numbers. However, in many practical situations, decision makers usually feel more confident to give interval judgments rather than expressing their judgments in the form of exact numeric values. Therefore, AHP technique involves subjectivity in pair-wise comparisons and vagueness and uncertainty dominate in this process. Combining AHP into the fuzzy system brings the fuzzy number of the fuzzy set theory directly into the pair-wise comparison matrix of the AHP. The purpose is to solve vague problems, which occur during the analysis of criteria and the judgment process. FAHP should be able to tolerate vagueness or ambiguity, and should thus be more appropriate and effective than conventional AHP in real practice. A fuzzy set is a class of objects with continuous grades of membership which represents the degree of truth as an extension of valuation. Fuzzy sets generalize classical sets while the indicator functions of these sets are special cases of the membership functions of fuzzy sets for the latter only take values 0 or 1 . Therefore, fuzzy analytic hierarchy process (FAHP), a fuzzy extension of AHP, was developed to solve the hierarchical fuzzy problems. In the FAHP procedure, the pairwise comparisons in the judgment matrix are fuzzy numbers that are modified by the designer's emphasis.

In order to create the landslide susceptibility map, the frequency ratio model was first used for calculate fuzzy membership. As previously mentioned, the frequency ratio is the ratio of the area where landslides occurred in the total study area, and also is the ratio of the probabilities of a landslide occurrence to a nonoccurrence for a given attribute [Bonham, 1994]:

$$
F R=\frac{D_{\mathrm{i}} / A_{\mathrm{i}}}{\sum_{\mathrm{i}=1}^{\mathbb{N}} D_{\mathrm{i}} / \sum_{\mathrm{i}=1}^{\mathbb{N}} A_{\mathrm{i}}}
$$

Where:

$D_{i}:$ is the area of landslide of the ith category

$\mathrm{A}_{\mathrm{i}}$ : is the area of the ith category in a certain parameter

$\mathrm{N}$ : is the category number of the parameter

\begin{tabular}{|c|c|c|c|c|c|}
\hline Factor & class & $\begin{array}{l}\text { Percentage of } \\
\text { landslide pixels }\end{array}$ & $\begin{array}{c}\text { Percentage pixels no } \\
\text { landslide }\end{array}$ & FR & $\begin{array}{c}\text { Fuzzy } \\
\text { membership }\end{array}$ \\
\hline \multirow{5}{*}{$\begin{array}{l}\text { Distance from } \\
\text { fault }(\mathrm{m})\end{array}$} & $0-1000$ & 28.57 & 13.39 & 2.13 & 1 \\
\hline & $1000-2000$ & 35.71 & 22.12 & 1.61 & 0.75 \\
\hline & $2000-3000$ & 28.57 & 23.42 & 1.21 & 0.57 \\
\hline & $3000-4000$ & 7.14 & 20.42 & 0.34 & 0.16 \\
\hline & $4000<$ & 0 & 18.69 & 0 & 0 \\
\hline \multirow{4}{*}{$\begin{array}{l}\text { Distance from } \\
\operatorname{road}(\mathrm{m})\end{array}$} & $0-1000$ & 78.57 & 37.29 & 2.1 & 1 \\
\hline & $1000-2000$ & 14.28 & 25 & 0.57 & 0.27 \\
\hline & $2000-3000$ & 7.14 & 15.24 & 0.46 & 0.22 \\
\hline & $3000<$ & 0 & 22.44 & 0 & 0 \\
\hline \multirow[t]{4}{*}{ Elevation (m) } & $500-1000$ & 21.42 & 11.23 & 1.9 & 1 \\
\hline & $1000-1500$ & 71.42 & 51.03 & 1.4 & 0.73 \\
\hline & $1500-2000$ & 7.14 & 18.61 & 0.38 & 0.2 \\
\hline & $2000<$ & 0 & 19.11 & 0 & 0 \\
\hline \multirow[t]{6}{*}{ Slope (\%) } & $0-5$ & 0 & 2.99 & 0 & 0 \\
\hline & $5-15$ & 7.14 & 9.24 & 0.77 & 0.49 \\
\hline & $15-30$ & 21.42 & 24.23 & 0.88 & 0.56 \\
\hline & $30-50$ & 50 & 42.12 & 1.55 & 1 \\
\hline & $50-70$ & 21.42 & 22.26 & 0.98 & 0.61 \\
\hline & $70<$ & 0 & 9.13 & 0 & 0 \\
\hline \multirow[t]{8}{*}{ Aspect } & North & 14.2 & 15.2 & 0.93 & 0.38 \\
\hline & Northeast & 21.42 & 8.8 & 2.43 & 1 \\
\hline & Southeast & 0 & 7.21 & 0 & 0 \\
\hline & South & 0 & 7.57 & 0 & 0 \\
\hline & Southwest & 7.14 & 9.75 & 0.73 & 0.3 \\
\hline & West & 7.14 & 11.97 & 0.59 & 0.24 \\
\hline & Northwest & 21.42 & 14.36 & 1.49 & 0.61 \\
\hline & South & 28.57 & 25.05 & 1.14 & 0.46 \\
\hline \multirow{5}{*}{$\begin{array}{l}\text { Distance from } \\
\text { river }(\mathrm{m})\end{array}$} & $0-50$ & 42.85 & 19.03 & 2.25 & 0.9 \\
\hline & $50-100$ & 28.57 & 13.03 & 2.19 & 0.88 \\
\hline & $100-150$ & 21.42 & 8.62 & 2.48 & 1 \\
\hline & $150-200$ & 7.14 & 6.19 & 1.15 & 0.46 \\
\hline & $200<$ & 0 & 53.11 & 0 & 0 \\
\hline \multirow[t]{4}{*}{ Land cover } & dense forest & 0 & 0.07 & 0 & 0 \\
\hline & Sparse forest & 21.42 & 48.96 & 0.43 & 0.26 \\
\hline & pasture & 14.28 & 11.8 & 1.2 & 0.73 \\
\hline & مناطق agriculture & 64.28 & 39.15 & 1.64 & 1 \\
\hline Lithology & JM & 0 & 0.85 & 0 & 0 \\
\hline
\end{tabular}




\begin{tabular}{|c|c|c|c|c|c|}
\hline & Pr & 0 & 1.62 & 0 & 0 \\
\cline { 2 - 6 } & $\mathrm{DKh}$ & 100 & 97.47 & 1.02 & 1 \\
\hline \multirow{3}{*}{ Precipitation } & $730-750$ & 7.142 & 20.167 & 0.35 & 0.3 \\
\cline { 2 - 6 } & $750<$ & 92.85 & 79.83 & 1.63 & 1 \\
\hline
\end{tabular}

Table 1. Spatial relationships between each factor and landslide and fuzzy membership values

The AHP methodology consists of pairwise comparison of all possible pairs of factors and try to synthesize the judgments to determine the weights (Saaty, 2001).in this study the relative rating for the dominance between each pair of factors was guided by expert knowledge. A comparison matrix of scores was created (Table 2). In this study, the value of CR is obtained by the ratio between the values of the indexes $\mathrm{CI}$ [matrix's consistency index, whose expression is shown in Eq. (2)] and a random index RI, which is the average consistency index. a CR lower than 0.1 would be acceptable (Ayalew et al. 2004), although this depends on the objective of the study.

$$
C_{I}=\frac{\lambda_{\max }-m}{m-1}
$$

Where $\lambda \max$ is the maximum eigenvalue of comparison matrix, and $m$ is the number of factors (nine in this study)

\begin{tabular}{|l|l|l|l|l|l|l|l|l|l|}
\hline $\begin{array}{l}\text { Weight-decision } \\
\text { matrix }\end{array}$ & $\begin{array}{l}\text { Precipita } \\
\text { tion }\end{array}$ & Slope & Lithology & Aspect & Land cover & $\begin{array}{l}\text { Distance } \\
\text { from road }\end{array}$ & $\begin{array}{l}\text { Distance } \\
\text { from fault }\end{array}$ & $\begin{array}{l}\text { Distance } \\
\text { from river }\end{array}$ & Elevation \\
\hline Precipitation & 1 & 2 & 2 & 3 & 4 & 3 & 3 & 4 & 7 \\
\hline Slope & 0.5 & 1 & 3 & 3 & 3 & 4 & 3 & 4 & 7 \\
\hline Lithology & 0.5 & 0.33 & 1 & 3 & 2 & 3 & 4 & 4 & 7 \\
\hline Aspect & 0.33 & 0.33 & 0.33 & 1 & 2 & 2 & 1 & 2 & 4 \\
\hline Land cover & 0.25 & 0.33 & 0.5 & 0.5 & 1 & 2 & 2 & 2 & 3 \\
\hline Distance from road & 0.33 & 0.25 & 0.33 & 0.5 & 0.5 & 1 & 2 & 1 & 4 \\
\hline Distance from fault & 0.33 & 0.33 & 0.25 & 1 & 0.5 & 0.5 & 1 & 2 & 3 \\
\hline Distance from river & 0.25 & 0.25 & 0.25 & 0.5 & 0.5 & 1 & 0.5 & 1 \\
\hline Elevation & 0.14 & 0.14 & 0.17 & 0.25 & 0.33 & 0.25 & 0.33 & 0.33 & 3 \\
\hline Weights & 0.243 & 0.218 & 0.167 & 0.089 & 0.080 & 0.065 & 0.063 & 0.049 \\
\hline
\end{tabular}

Table 2. Pairwise comparison matrix of scores for calculating weights

After obtaining weight of each parameters, they is multiplied in the map calculated by frequency ratio and fuzzy membership and the result of them is show in the below figure in the Fig 4.

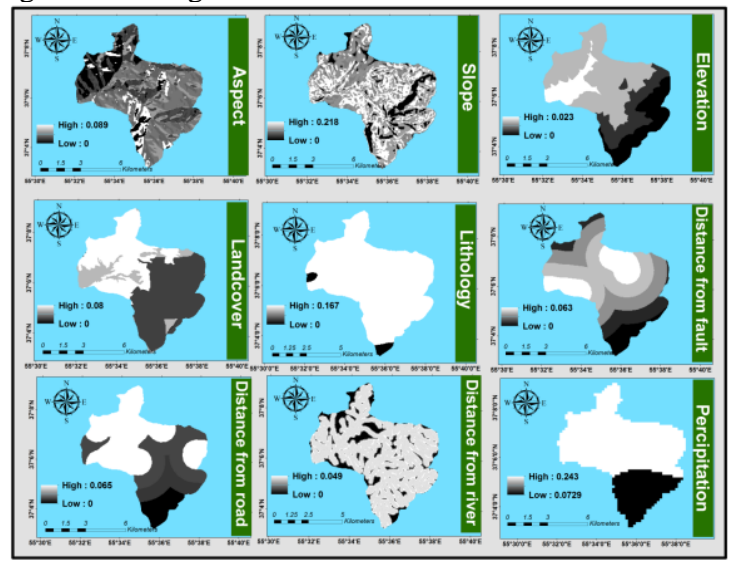

Figure 4. FAHP maps of input data layers

At the end maps obtained using FAHP of the each factor was incorporated to have the landslide hazard zonation map based on the most susceptible fuzzy operator (Malekian et al, 2012)

$$
\mu_{\text {combination }}=1-\prod_{\mathrm{i}=1}^{\mathrm{m}}\left(1-\mu_{\mathrm{i}}(x)\right)
$$

Where $\mu_{i}$ is the fuzzy membership function for its map, and $\mathrm{i}=1,2 \ldots \mathrm{n}$ maps are to be combined(zimerman,1996).

Then, the final map was classified into five classes based on standard deviation (Fig 5)

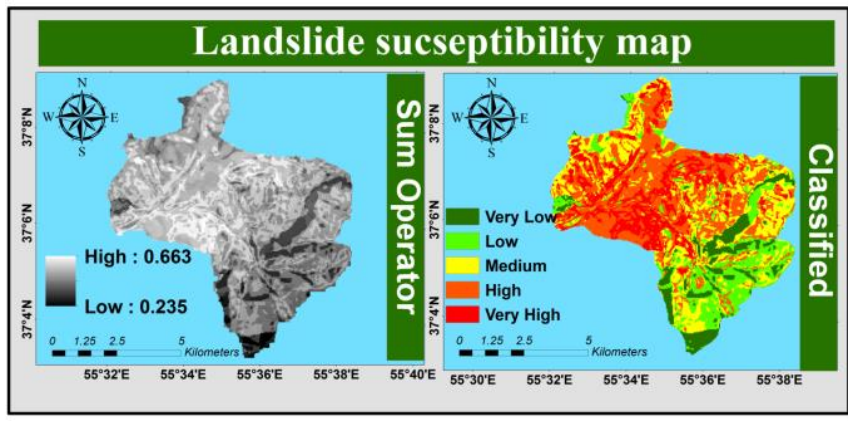

Figure 5. Landslide susceptibility maps

\section{Validation}

The landslide-susceptibility analysis results were verified using the existing landslide locations in the study area and ROC (receiver operating characteristics) method. This curve are obtained by plotting all combinations of sensitivities (on the y-axis) and proportions of false negatives (1-specifity; on the $\mathrm{x}$-axis) that may be obtained by varying the decision threshold (Brenning, 2005) In the AUC method, the AUC, with values ranging from 0.5 to 1.0 , is used to assess the accuracy of the constructed model. The AUC defines the quality of the probabilistic model by describing its ability to reliably predict an occurrence or nonoccurrence event (Remondo et al., 2003). An ideal model presents an AUC value close to 1.0 , whereas a value close to 0.5 indicates inaccuracy in the model (Fawcett, 2006). The AUC value of the ROC curve for this study was found to be 0.7354 (Fig.6) 
ROC Curve for $y=0.24 \operatorname{Ln}(x)+0.97$

Area under curve $=0.7354$

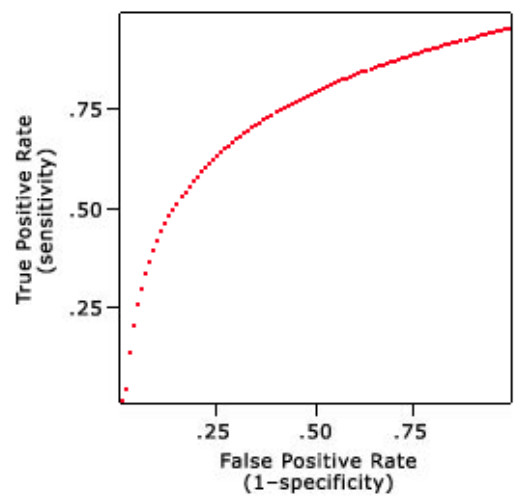

Figure 6. ROC curve for the susceptibility maps produced in this study

Result of this final landslide susceptibility map is shown in the Fig 7

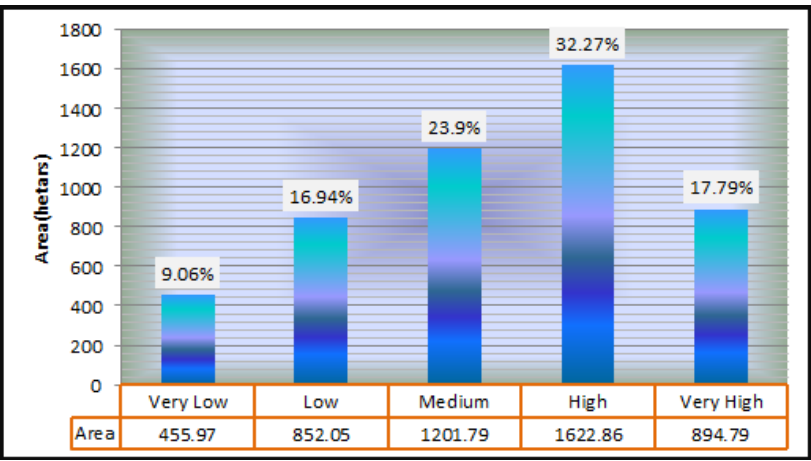

Figure7. Histogram of calculated landslide susceptibility map showing the relative areas for each susceptibility class ((susceptibility classes are labelled with the percent of total area accordingly

in According to Fig7 about 51 percent (2517 ha) of the study area fall into the high and very high .In addition about $27 \%$ of total area fall into the low and very low susceptibility zones which covers approximately about 1308 hectares of study area.

\section{CONCLUSION}

Landslide is one of environmental phenomenon's, which sometimes occur in some parts of Golestan province. Therefore, creation of one regional strategy is very necessary to reduce its damages and maintains natural and human resources. In this study, based on Fuzzy Logic, Frequency Ratio and Analytical Hierarchy Process model and nine data layers the landslide susceptibility in the Dozein basin was assessed, then using ROC, curve these results were verified. The validation results showed that the area under the curve for this study is 7354 . The assessment results show that the relatively safe areas that more than $51 \%$ of landslides are distributed in the "very high" and "high" areas, while less than $27 \%$ of landsides occurred in the "Very low" and
"Low" areas. According to Landslide susceptibility map, most agriculture (residential areas) together with the pasture fall in both very high and high susceptible zone, and most of very low and low class fall into dense forest area that indicating that human activities played an important role in the landslide occurrence. Therefore, the results of such studies can be used for mitigating the hazard and is very helpful to planners and engineers for choosing suitable locations to carry out developments. To prevent or reduce the risks of landslide in the study area, it is recommended to prevent of degradation and change in natural vegetation.

\section{REFERENCES}

Ayalew L, Yamagishi H, Ugawa N., 2004, Landslide susceptibility mapping using GISbased weighted linear combination, the case in Tsugawa area of Agano River, Niigata Prefecture, Japan. Landslides 1(1):73-81

Ayalew L,Yamagishi H., 2005, The application of GIS-based logistic regression for landslide susceptibility mapping in the Kakuda-Yahiko Mountains, Central Japan. Geomorphology 65(1/2):15-31

Bonham-Carter GF., 1994, Geographic information systems for geoscientists, modeling with GIS. Pergamon, Oxford, 398 $\mathrm{pp}$

Brabb, E.E., 1984. Innovative approaches to landslide hazard mapping. Proceedings of Fourth International. Symposium on Landslides, Toronto, pp. 307-324.

Brenning, A., 2005. Spatial prediction models for landslide hazards: review, comparison and evaluation. Natural Hazards and Earth System Sciences 5, 853-862.

Caniani D, Pascale S, Sado F, Sole A., 2008, Neural networks and landslide susceptibility: a case study ofthe urban area of Potenza. Nat Hazards 45:55-72

Carrara A., 1983, A multivariate model for landslide hazard evaluation. Math Geol 15:403-426

Champati ray,P.K; Dimri, Suvarna; Lakhera, R. C.; Sati, Santosh., 2007 Fuzzy-based method for landslide hazard assessment in active seismic zone of Himalaya; Landslides, $4: 101-111$

Cheng Z, Wang J., 2007, Landslide hazard mapping using logistic regression model in Mackenzie Valley,Canada. Nat Hazards 42:75-89

Creighton R., 2006, A Report of the Irish Landslides Working Group; Geological Survey of Ireland 2006;pp1-109

Dai FC, Lee CF, Li J, Xu ZW., 2001, Assessment of landslide susceptibility on the natural terrain of Lantau Island, Hong Kong. Environ Geol 43(3):381-391

DeGraff, J., Romesburg, H., 1980. Regional landslide susceptibility assessment for wildland management: a matrix approach. In: Coates, D., Vitek, J. (Eds.), Thresholds in Geomorphology. George Allen and Unwin, London, pp. 401-414.

Ercanoglu M, Gokceoglu C., 2004, Use of fuzzy relations to produce landslide susceptibility map of a landslide prone area 
(West Black Sea Region, Turkey). Eng Geol 75(3-4):229250

Faraji Sabokbar H; Shadman Roodposhti,M; Tazik,E., 2014, Landslide susceptibility mapping using geographicallyweighted principal component analysis , Geomorphology, InPress

Fawcett, T., 2006. An introduction to ROC analysis. Pattern Recognition Letters 27, 861-874.

Gee. M.D., 1991, Classification of landslide hazard zonation methods and a test of predictive capability, Landslides, Balkema, Rotterdam, 947- 952.

Greenbaum, D., Tutton, M., Bowker, M., Browne, T., Buleka, J., Greally, K., Kuna, G., McDonald, A., Marsh, S., O'Connor, E., Tragheim, D., 1995. Rapid Methods of Landslide Hazard Mapping: Papua New Guinea Case Study. British Geological Survey. Technical Report WC/95/27.

Hatamifar, R; Mousavi, S.H; Alimoradi, M., 2012., Landslide hazard zonation using AHP model and GIS technique in Khoram Abad City; Geomorphology and environmental planning, 23(3): 43-60

Jordan, C., O'Connor, E., Marchant, A., Northmore, A., Greenbaum, D., McDonald, A., Kovacik, M., Ahmed, R., 2000. Rapid landslide susceptibility mapping using remote sensing and GIS modelling. Proc. 14th International Conference on Applied Geologic Remote Sensing, Las Vegas, pp. 113-120

Kayastha,P; Dhital, M.R; Smedt, F. De., 2013, Application of the analytical hierarchy process (AHP) for landslide susceptibility mapping: A case study from the Tinau watershed, west Nepal; Computers \& Geosciences 52, 398408

Khezri, Saeed., 2010, Landslide susceptibility in the Zab Basin, northwest of Iran, Procedia - Social and Behavioral Sciences ; 19;726-731

Iovine G., 2008, Mud-flow and lava-flow susceptibility and hazard mapping through numerical modelling,GIS techniques, historical and geo-environmental analyses. In: Proceedings of the iEMSs 4th biennial meeting, international congress on environmental modelling ANS software: integrating sciences and information technology for environmental assessment and decision making (iEMSs2008), vol 3, pp 1447-1460

Malekian A., Oftadegan Khuzani A. Ashurnejad Q., 2012, Flood Hazard Zoning in Watershed Scale using Fuzzy Logic (Case study: Akhtar Abad Watershed), Physical Geography Research Quarterly, No. 176, PP. 131-152.

Marston, R., Miller, M., Devkota, L., 1998. Geoecology and mass movements in the Manaslu Ganesh and Langtang-Jural Himals, Nepal. Geomorphology 26, 139- 150.

Mittal, S.K.,Singh, M., Kapur, P.,Sharma, B.K., Shamshi, M.A., 2008. Design nd development of instrument network for landslide monitoring, an issue an early warning. Journal of Scientific \&Industrial research 67,361-365.
Nielsen TH, Wrigth RH, Vlasic TC, Spangle WE., 1979, Relative slope stability and land-use planning in the San Francisco Bay region, California. US geological survey professional paper 944

Perriello Zampelli S, Bellucci Sessa E, Cavallaro M., 2012, Application of a GIS-aided method for the assessment of volcaniclastic soil sliding susceptibility to sample areas of Campania (Southern Italy).Nat Hazards 61(1):155-168

Pourghasemi, Hamid Reza; Moradi, Hamid Reza; Fatemi Aghda, said mahmood; Mahdavifar, mohammad Reza; Mohammdi, majid., 2009, andslide Hazard Assessment Using Fuzzy Multi Criteria Decision- Making Method; Iranian Jornal of Watershed Management Science\&Engineering, 3(8): 51-62

Remondo, J., Gonzàlez-Diez, A., Dìaz de Teràn, J.R., Cendrero, A., 2003. Landslides susceptibility models utilising spatial data analysis techniques. A case study from the lower Deba Valley, Guipùzcoa (Spain). Natural Hazards $30,267-279$.

Saaty LT, Vargas LG., 2001, Models, methods, concepts, and applications of the analytic hierarchy process. Kluwer Academic, Boston, p 333

Saito, Hitoshi; Nakayama, Daichi; Matsuyama, Hiroshi., 2009, Comparison of landslide susceptibility based on a decision-tree model and actual landslide occurrence: The Akaishi Mountains, Japan; Geomorphology 109 (2009) 108121

Shadman Roodposhti.M, Rahimi. S, Jafar Beglou. M., 2012, PROMETHEE II and fuzzy AHP: an enhanced GIS-based landslide susceptibility mapping, Nat Hazards DOI 10.1007/s11069-012-0523-8

Wang L J, Sawada,K; Moriguchi, S., 2013, Landslide susceptibility analysis with logistic regression model based on FCM sampling strategy, Computers \&Geosciences57,8192

Zimmerman HJ., 1996, Fuzzy set theory and it applications. Kluwer, Massachusetts, 435 pp 